\title{
The chemical composition of different types and varieties of pea and the digestion of their protein in pigs
}

\author{
Jolanta Gdala, Lucyna Buraczewska and W. Grala
}

The Kielanowski Institute of Antmal Phvsiology and Nurtiton, Polish Academy of Sciences 05-110 Jablonna, Poland

(Received 29 August 1991; accepted 29 November 1991)

\begin{abstract}
Six varieties of white-flowered and three varietics of coloured-flowered peas were analysed for content of nutrients and some antinutritional factors. In a trial on cannulated pigs, jleal and total digestibility of protein and amino acids were estimated. The coloured-flowered varieties of pea contained significantly more NDF $(P<0.05)$, Klason lignin and tannins $(P<0.01)$ than the white-flowered ones. The trypsin inhibitor activity ranged widely in both white- and coloured-flowered peas. Methionine, cystine and threonine were negatively correlated with the protein content of the tested seeds. The true ileal and faceal digestibilities of pea protein singed from 66 to 83 and from 74 to 88 , respectively. The greatest differences among the peas in ileal amino acid digestibility occurred for methionine, cyst ine and tryptophane. It was found that among the analysed factors (NDF, Lannins, trypsin inhibitor) only NDF significantly decreased the ileal digestibility of protein. The faceal digestibility was mainly reduced by tannin content.
\end{abstract}

KEY WORDS; pea, pigs, ileal digestibility, amino acids

\section{INTRODUCTION}

In recent years an interest in the production of pea as a protein source for pigs has grown considerably. Two subspecies of Pisum sativum are cultivated in Poland: P. sativum arvense which has dark-coloured flowers and is mainly used in animal feeding and white-flowered $P$. sativum hortense which is used for human nutrition and for monogastic animals, especially for pigs. Since the leve] of protein and some amino acids, especially methionine, in pea is low, it is important to have accurate knowledge about all of the factors which can influence the protein digestibility and amino acid availability in the pig. Several papers indicate that tamnins influence nutrient digestibility by their ability to complex with proteins (Griffiths, 1979; Griffiths and Moseley, 1980), so exerting harmful effect on animal organs (McLeod, 1974). Protease inhibitors may also interfere with protein digestibility (Griffiths, 1984; Leterme et al., 1990a).

(C) Institute of Animal Physiology and Nutrition 
The subject of this study was to determine the chemical composition of pea seeds, to compare the true ileal and faecal digestibility of protein and amino acids of both white and coloured flowered spring peas and to find factors influencing these digestibilities. The aim of the research was to look for indicators permitting prediction of amino acid digestibility of peas on the basis of their chemical composition.

\section{MATERIAL AND METHODS}

Seeds (sowing grade) of six varieties of white-flowered pea (varieties: Belinda - batches 1 and 2, Kaliski, Mige, Opal, Milewska, Koral) and three varieties of coloured-flowered pea (varieties: Matmal, Mazurska, Gomik) were analysed and used in the experiment, which was carried out on Large White $x$ Landrace castrated male pigs of 30 to $80 \mathrm{~kg}$. The ileum of each of the animals was cannulated with a T-shaped fistula (internal diameter $22 \mathrm{~mm}$ ) inserted approximately $15 \mathrm{~cm}$ anterior to the ileo-caecal junction, according to the method described by Horszczaruk et al. (1972).

The pigs were fed barley diets containing $41.5 \%$ of the tested peas (Table 1). For true digestibility estimation a starch-barley (control) diet was prepared. Each diet was offered every $12 \mathrm{~h}$ to $4-6$ pigs at the level of $3.8 \%$ body mass per day.

Ten days after the surgical operation the animals were placed in metabolic cages. After seven days of adaptation period faeces ( 3 days) and digesta (at least $3 \times 12 \mathrm{~h}$ ) were collected.

The ground pea seeds, diets and freeze-dried samples of digesta and faeces were analysed for content of protein, amino acids and neutral detergent fibre (NDF) according to methods described by Buraczewska et al. (1987).

The tannin content in pea seeds was determined according to the method of Jerumanis (1972) modified by Adams nad Novellie (1975). The trypsin inhibitor activity was estimated by the method of Kakade et al. (1974).

True ileal and total digestibilities of pea total nitrogen and amino acids were

TABLE 1.

Composition of diets, $\%$

\begin{tabular}{lcc}
\hline \multicolumn{1}{c}{ Ingredients } & \multicolumn{2}{c}{ Diets } \\
\cline { 2 - 3 } & Control & Experimental \\
\hline Barley & 51.70 & 51.70 \\
Maize starch & 43.45 & 2.70 \\
Pea & - & 41.50 \\
Min. - vit. mixture & 4.40 & 3.80 \\
$\mathrm{Cr}_{2} \mathrm{O}_{3}$ & 0.30 & 0.30 \\
$\mathrm{~L}-\mathrm{Lys} \cdot \mathrm{HCl}$ & 0.15 & \\
\hline
\end{tabular}


calculated by the difference method using the digestibility of the barley-starch diet as a reference.

All statistical tests were performed using Statgraphics version 2.1. Mean values in table 4 and 5 were compared by the one-way Anova test. True ileal digestibilities of amino acids were regressed on true ilcal digestibility of protein using a simple linear regression.

\section{RESULTS AND DISCUSSION}

\section{Chemical composition of tested peas}

The results shown in Table 2 indicate that the protein $(\mathrm{N} \times 6.25)$ content in dry matter ranged from 21 to $28 \%$ with a mean of $24.8 \%$ for the white-flowered peas and $23.5 \%$ for the coloured-flowered varieties. These results are similar to those obtained by Bajaj et al. (1971), who reported a protein content varying from 21.2 to $28.5 \%$. The values given by Reichert and McKenzie (1982) are even more differentiated (from 14.5 to $28.5 \%$ ).

As it is seen in Table 2, the coloured-flowered peas contained more tannins $(\mathrm{P}<0.01)$ than the white-flowered varieties. These results are in agreement with

TABLE 2

Chemical composition of peas

\begin{tabular}{|c|c|c|c|c|c|c|}
\hline $\begin{array}{c}\text { Pea } \\
\text { variety }\end{array}$ & DM & $C P^{11}$ & NDF $^{1}$ & $\begin{array}{c}\text { Klason }{ }^{11} \\
\text { lignin }\end{array}$ & Tannins $^{21}$ & $\begin{array}{l}\text { Trypsin }^{31} \\
\text { inhibitor }\end{array}$ \\
\hline \multicolumn{7}{|l|}{ White-flowered } \\
\hline Belinda 1 & 87.2 & 27.7 & 11.8 & 0.62 & 1.84 & 0.77 \\
\hline Kaliski & 85.9 & 26.3 & 12.7 & 0.81 & 1.57 & 2.19 \\
\hline Mige & 85.7 & 26.1 & 11.7 & 1.10 & 1.75 & 8.73 \\
\hline Belinda 2 & 85.7 & 26.1 & 13.4 & 0.70 & 1.97 & 3.12 \\
\hline Opal & 85.2 & 22.4 & 12.6 & 0.60 & 2.63 & 6.47 \\
\hline Milewska & 85.5 & 22.6 & 15.7 & 1.50 & 2.42 & 8.27 \\
\hline Koral & 86.3 & 22.1 & 12.6 & 0.65 & 2.09 & 6.13 \\
\hline$\overline{\mathbf{x}}$ & 85.9 & $24.8^{a}$ & $12.9^{\circ}$ & $0.85^{\mathrm{A}}$ & $2.04^{A}$ & $5.10^{u}$ \\
\hline \multicolumn{7}{|c|}{ Coloured-flowcred } \\
\hline Matmal & 84.5 & 26.6 & 17.2 & 2.10 & 7.32 & 6.39 \\
\hline Mazurska & 87.5 & 22.7 & 14.3 & 2.56 & 7.17 & 4.27 \\
\hline Gomik & 85.1 & 21.1 & 15.8 & 1.78 & 8.02 & 15.94 \\
\hline $\bar{x}$ & 85.7 & $23.5^{\alpha}$ & $15.8^{h}$ & $2.15^{\mathrm{R}}$ & $7.50^{8}$ & $8.87^{\circ}$ \\
\hline
\end{tabular}

1) \% of DM; ${ }^{2)} \mathrm{mg} / \mathrm{g} \mathrm{DM}$; ${ }^{\text {3) TIU } / \mathrm{mg} \mathrm{DM}}$

$\mathrm{A}, \mathrm{B}$-differences in column significant at $\mathrm{P}<0.01 ; \mathrm{a}, \mathrm{b}-$ at $\mathrm{P}<0.05$ 
TABLE 3

Amino acid composition of pea protein (g/16 g N)

\begin{tabular}{|c|c|c|c|c|c|c|c|c|c|c|}
\hline \multirow{2}{*}{$\mathrm{AA}^{11}$} & \multicolumn{7}{|c|}{ Pea varicties } & \multicolumn{3}{|c|}{ coloured-flowered } \\
\hline & $\begin{array}{l}\text { Belin- } \\
\text { da } 1\end{array}$ & $\begin{array}{c}\text { Kali- } \\
\text { ski }\end{array}$ & Mige & $\begin{array}{l}\text { Belin- } \\
\text { da } 2\end{array}$ & Opal & $\begin{array}{l}\text { Mile- } \\
\text { wska }\end{array}$ & Koral & $\begin{array}{c}\text { Mat- } \\
\text { mal }\end{array}$ & $\begin{array}{c}\text { Mazur- } \\
\text { skd }\end{array}$ & Gomik \\
\hline$C P$ & 27.7 & 26.3 & 26.1 & 26.1 & 22.4 & 22.6 & 22.1 & 26.6 & 22.7 & 21.1 \\
\hline Lys & 7.02 & 7.22 & 7.53 & 7.51 & 7.98 & 7.66 & 7.45 & 7.32 & 7.50 & 7.22 \\
\hline Met & 0.87 & 0.89 & 1.01 & 0.98 & 0.99 & 1.16 & 1.06 & 0.97 & 1.11 & 1.11 \\
\hline Cys & 1.33 & 1.49 & 1.38 & 1.36 & 1.42 & 1.74 & 1.64 & 1.42 & 1.76 & 1.91 \\
\hline Thr & 3.37 & 3.44 & 3.82 & 3,74 & 3.89 & 3.97 & 4.16 & 3.75 & 3.88 & 3.92 \\
\hline Trp & 0.84 & 0.84 & 0.97 & 0.90 & 0.87 & 1.12 & 0.96 & 1.02 & 1.00 & 0.99 \\
\hline Ile & 3.89 & 4.02 & 4.25 & 4.12 & 4.29 & 4.40 & 4.44 & 4.28 & 3.88 & 3.92 \\
\hline Leu & 6.75 & 6.91 & 7.38 & 6.98 & 7.27 & 7.39 & 7.55 & 7.34 & 7.47 & 7.01 \\
\hline Phe & 4.23 & 4.60 & 5.13 & 4.71 & 4.86 & 5.03 & 5.12 & 4.83 & 4.88 & 4.68 \\
\hline Val & 4.48 & 4.65 & 4.84 & 4.76 & 4.81 & 4.97 & 4.98 & 4.94 & 4.87 & 4.78 \\
\hline Tyr & 2.75 & 2.92 & 3.17 & 2.99 & 3.06 & 3.34 & 3.43 & 3.15 & 3.19 & 3.03 \\
\hline
\end{tabular}

11 amino acids

the results obtained by Griffiths (1981) who found on average twice more polyphenols (tannic acid equivalents) in seeds of coloured-flowered peas than in those of white-flowered ones.

The seeds of Gomik, Mige and Milewska peas had high trypsin inhibitor activity, which is usually attributed to winter varieties (Valdebouze et al.. 1980; Gatel and Grosjean, 1990). Leterme et al. (1990a) reported that trypsin inhibitor activity of spring type of peas ranged from 1.71 to $8.40 \mathrm{TIU}^{-1} \mathrm{DM}$, while that of winter varieties varied from 11.4 to $16.8 \mathrm{TIU}^{-1} \mathrm{DM}$. There is no evidence explaining such large differences between peas. Probably, growing conditions and degree of ripeness of seeds could influence their chemical composition (Holl and Vose, 1980), including trypsin inhibitor activity. Analysis of fibre fractions showed higher contents of NDF $(P<0.05)$ and Klason lignin $(P<0.01)$ in coloured-flowered peas than in white-flowered ones.

Amino acid analysis of the pea protein (Table 3 ) showed a relatively low level of methionine from 0.87 to $1.16 \mathrm{~g}$ and high content of lysine from $7.02 \mathrm{to} 7.98 \mathrm{~g}$ per $16 \mathrm{~g} \mathrm{~N}$. Seeds of white-flowered peas Milewska and Koral and coloured-flowered varieties Mazurska and Gomik contained comparatively higher levels of methionine and cystine than other varieties. It was found that methionine $(r=-0.84)$, cystine $(r=-0.826)$, threonine $(r=-0.806)$, alanine $(r=-0.810)$, glycine $(r=-0.706)$ and serine $(r=-0.675)$ were negatively correlated with the protein level. Reichert and McKenzie (1982), who analysed the amino acid composition of 198 samples of pea, obtained a similar correlation 
for these amino acids. In addition, they found a significant negative correlation for lysine and a positive one for glutamic acid. Evans and Boutler (1980) have found a negative correlation between sulphur-containing amino acids and the protein content for both peas and beans.

\section{True ileal and faecal digestibility of pea protein and amino acids}

The true ileal digestibility of protein (Table 4) was higher for white-flowered peas than for coloured-flowered ones and ranged from 71 to 83 and 66 to 69 , respectively. Calculations showed that the protein digestibility was negatively correlated with content of NDF, tannins and trypsin inhibitor in pea seeds. However, the effect of NDF was highest and statistically significant at $\mathrm{P}<0.05$.

Żebrowska et al. (1981) reported that increasing the level of straw or cellulose in diets $(5 \%$ or $10 \%)$ decreased the apparent ileal and faecal digestibility of nitrogen. Stanogias and Pearce (1985) found that not only the amount but also the type of dietary fibre significantly influenced the apparent digestibility of dry matter, nitrogen and energy.

The highest digestibilities of amino acids were found for arginine (72-93), histidine (65-88) and lysine (69-85), which is in agreement with the results obtained by Leterme et al. (1990b). The lowest digestibilities were found for cystine (48-68) and for tryptophane (53-69). Knabe et al. (1989) reported that arginine was the most digestible essential amino acid, while threonine and tryptophane were the least digestible ones in 30 samples of different feedstuffs. In our trials, threonine was digested from 63 to 84 per cent. The low apparent digestibility of this amino acid can be influenced by high concentriaton of thereonine in endogenous secreta reaching the end of the ileum (Taverner et al., 1981; Leterme et al., 1990b). Among the tested peas the greatest differences in ileal digestibility of amino acids occurred for methionine, tryptophane and cystine (25,24 and 20 percentage units, respectively). Results of simple regression analysis indicate a relationship between ileal protein digestibility $(\mathrm{x})$ and ileal amino acid digestibilities (Y):

1. $Y_{\text {Lys }}=15.84+0.82 \mathrm{x} \pm 2.7 \quad \mathrm{r}=0.869 \quad \mathrm{P}<0.01$

2. $Y_{\text {Me1 }}=-41.03+1.44 x \pm 4.8 \quad r=0.892 \quad P<0.01$

3. $Y_{C y s}=0.75+0.83 x \pm 6.9 \quad r=0.562 \quad P<0.01$

4. $\mathrm{Y}_{\mathrm{Thr}}=-11.10+1.12 \mathrm{x} \pm 3.1 \quad \mathrm{r}=0.899 \quad \mathrm{P}<0.01$

However, the obtained data suggest that ileal protein digestibility can not be used with a high degree of accuracy to predict ileal sulphur-containing amino acid digestibilities, especially cystine. 
True ileal digestibility of protcin and amino acids of different peas fed to pigs

TABLE 4

\begin{tabular}{|c|c|c|c|c|c|c|c|c|c|c|}
\hline \multicolumn{11}{|c|}{ Pea } \\
\hline \multicolumn{8}{|c|}{ white-flowered } & \multicolumn{3}{|c|}{ coloured-flowered } \\
\hline & Belinda 1 & Kaliski & Mige & Belinda 2 & Opa] & Milewska & Korak & Matmal & Mazurska & Gomik \\
\hline $\mathrm{N} \times 6,25$ & $82,5^{\mathrm{C}}$ & $78,1^{\mathrm{BC}}$ & $75,9^{\mathrm{BC}}$ & $74,0^{A B C}$ & $73,2^{\mathrm{ABC}}$ & $70,5^{\mathbf{A P}}$ & $73,5^{\mathrm{ABC}}$ & $65,8^{\mathrm{A}}$ & $68,0^{\mathrm{AR}}$ & $68,4^{\mathrm{AB}}$ \\
\hline Lys & $84,7^{C}$ & $81,5^{\mathrm{BC}}$ & $79,5^{\mathrm{BC}}$ & $75,0^{\mathrm{ABC}}$ & $75,6^{\mathrm{ABC}}$ & $72,6^{A B}$ & $77,0^{A B C}$ & $72,4^{\mathbf{A B}}$ & $74,2^{\mathrm{AB}}$ & $69,0^{A}$ \\
\hline Met & $78,9^{3}$ & $71,1^{\mathrm{BCD}}$ & $73,5^{\mathrm{CD}}$ & $66,2^{\mathrm{ABCD}}$ & $59,7^{\mathrm{ABC}}$ & $59,9^{\text {ABCD }}$ & $63,9^{\mathrm{AB}}$ & $60,0^{\mathrm{AB}}$ & $56,6^{\mathrm{A}}$ & $54,1^{\wedge}$ \\
\hline Cys & $68,2^{\text {म }}$ & $67,5^{\mathrm{B}}$ & $59,0^{\mathrm{AB}}$ & $63,4^{\mathrm{B}}$ & $52,1^{\mathrm{A}}$ & $65,8^{\mathrm{B}}$ & $65.9^{\mathrm{B}}$ & $47,9^{A}$ & $59,2^{\mathrm{AB}}$ & $60,1^{A B}$ \\
\hline Thr & $83,9^{\mathrm{B}}$ & $74,9^{\mathrm{AB}}$ & $74,6^{\mathrm{AB}}$ & $72,6^{+3}$ & $69.9^{A}$ & $69,2^{\mathrm{A}}$ & $69,3^{\mathrm{A}}$ & $64,7^{\mathrm{A}}$ & $64,9^{A}$ & $63,0^{A}$ \\
\hline Trp & $76,8^{\mathrm{D}}$ & $69,1^{\mathrm{CD}}$ & $68.7^{\mathrm{BCD}}$ & $68.1^{\mathrm{D}}$ & $59,3^{\mathrm{AHC}}$ & $66,4^{\mathrm{BCD}}$ & $64,3^{A B C D}$ & $57,7^{\mathrm{ABC}}$ & $54,9^{\mathrm{AB}}$ & $53,1^{A}$ \\
\hline Ile & $87,7^{\mathrm{C}}$ & $77,8^{\mathrm{BC}}$ & $74,7^{\mathrm{AB}}$ & $74,7^{\mathrm{AB}}$ & $73,6^{\mathrm{AH}}$ & $69,8^{\mathrm{AR}}$ & $75,1^{\mathrm{AB}}$ & $77,5^{\mathrm{AB}}$ & $67,7^{\text {AB }}$ & $67,5^{\mathrm{A}}$ \\
\hline Arg & $93,3^{\mathbf{D}}$ & $89,2^{\mathrm{CD}}$ & $88,0^{\mathrm{BCV}}$ & $88,2^{\mathrm{CD}}$ & $85,8^{\mathrm{RC}}$ & $83,4^{\mathrm{ARC}}$ & $88,4^{C D}$ & $72,2^{\mathrm{AB}}$ & $82,9^{A n}$ & $79,9^{\mathbf{A}}$ \\
\hline $\mathrm{His}$ & $87,7^{\mathrm{C}}$ & $82,2^{\text {ARC }}$ & $80,6^{A B C}$ & $79.9^{\mathrm{ABC}}$ & $77.5^{\mathrm{AH}}$ & $80,3^{\mathrm{ABC}}$ & $85,3^{\mathrm{BC}}$ & $65,3^{\mathrm{A}}$ & $76,3^{\mathrm{AH}}$ & $72,9^{A}$ \\
\hline Lev & $86,2^{\mathrm{C}}$ & $79.9^{\mathrm{BC}}$ & $76,3^{\mathrm{BC}}$ & $76,0^{\mathrm{BC}}$ & $74,8^{\mathrm{AB}}$ & $68,8^{A B}$ & $74,1^{\mathrm{AB}}$ & $68,7^{\mathrm{AB}}$ & $69,0^{\mathrm{AB}}$ & $64,3^{\mathrm{A}}$ \\
\hline Phe & $87,2^{\mathrm{D}}$ & $79,3^{\mathrm{CD}}$ & $76,1^{\mathrm{ABCD}}$ & $77,1^{\mathrm{CD}}$ & $74,9^{\text {AHC }}$ & $72,4^{\mathrm{ABC}}$ & $76,6^{\mathrm{BCD}}$ & $83,9^{\mathrm{A}}$ & $66,9^{\mathrm{ABC} C}$ & $65,5^{\wedge \mathrm{B}}$ \\
\hline Val & $84,4^{\mathrm{B}}$ & $75,5^{\mathrm{AB}}$ & $73,3^{A B}$ & $72,2^{\mathrm{A}}$ & $71,9^{\mathrm{A}}$ & $69,4^{\mathrm{A}}$ & $70,6^{\mathrm{A}}$ & $64,8^{A}$ & $66,6^{\mathrm{A}}$ & $65,1^{A}$ \\
\hline Ala & $83,1^{\mathrm{C}}$ & $75,3^{\mathrm{ABC}}$ & $72,5^{\mathrm{ABC}}$ & $67,1^{\mathrm{BC}}$ & $69,6^{\mathrm{AB}}$ & $64,2^{A B}$ & $65,2^{\mathrm{AB}}$ & $63,6^{A B}$ & $63,1^{A B}$ & $62,1^{A}$ \\
\hline Asp & $89,0^{F}$ & $83.5^{\mathrm{EF}}$ & $80,0^{\mathrm{BCOE}}$ & $81,2^{\mathrm{CDH}}$ & $80,0^{\mathrm{BCDE}}$ & $75,5^{\mathrm{ABC}}$ & $82.5^{\mathrm{DEF}}$ & $75,8^{A B C D}$ & $73,1^{\mathrm{AP}}$ & $72,6^{\mathrm{A}}$ \\
\hline Glu & $86,4^{c}$ & $78,6^{\text {AHC }}$ & $81,0^{\text {ABC }}$ & $79,4^{\wedge \mathrm{AC}}$ & $77,3^{\text {АВC }}$ & $72,4^{\mathrm{A}}$ & $81,4^{\mathrm{BC}}$ & $72,6^{\wedge \mathrm{B}}$ & $71,6^{\mathrm{A}}$ & $71,9^{\mathrm{A}}$ \\
\hline Gly & $76,9^{\mathrm{B}}$ & $70,7^{\mathrm{AB}}$ & $63,4^{\mathrm{AB}}$ & $56,7^{\mathrm{AB}}$ & $55,7^{\mathrm{A}}$ & $70,2^{\mathrm{AB}}$ & $70,1^{\text {A }}$ & $56,0^{A}$ & $64,8^{\mathrm{AB}}$ & $59,1^{\text {AB }}$ \\
\hline Pro & $83,6^{\mathrm{CE}}$ & $74,6^{\mathrm{CDE}}$ & $55,2^{\mathrm{ABCDE}}$ & $49,3^{\mathrm{AB}}$ & $53.7^{\text {ARCD }}$ & $62,4^{\mathrm{ABCDE}}$ & $64,8^{\mathrm{ARCOE}}$ & $41,6^{\mathbf{A}}$ & $74,4^{\mathrm{BCDE}}$ & $52,9^{\mathrm{ABC}}$ \\
\hline Ser & $84,6^{C}$ & $77,0^{\mathrm{BC}}$ & $74,6^{\mathrm{AB}}$ & $75,5^{\mathrm{B}}$ & $71,9^{\mathrm{AR}}$ & $7 \mathrm{I}, 7^{\mathrm{AB}}$ & $72,9^{\mathrm{AB}}$ & $65,9^{\mathrm{A}}$ & $68,3^{\mathrm{AB}}$ & $67,2^{\mathrm{A}}$ \\
\hline Tyr & $87,7^{\mathrm{EG}}$ & $80,5^{\text {DFFG }}$ & $76,8^{\mathrm{BCDF}}$ & $76.9^{\mathrm{CDFF}}$ & $74,5^{\wedge \mathrm{BCD}}$ & $72,5^{\mathrm{ABCD}}$ & $76,3^{\mathrm{HCD}}$ & $68,8^{\mathrm{ABC}}$ & $65,0^{4}$ & $67,1^{A B}$ \\
\hline
\end{tabular}

Values within a row with the same superscript were not significantly different $(P<0.01)$ 
崫

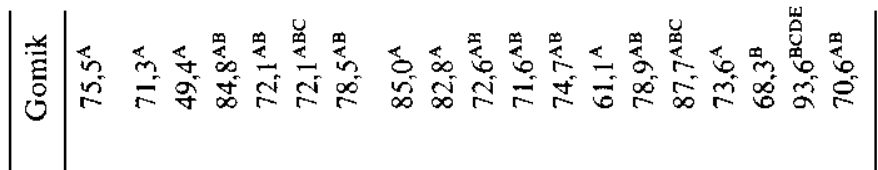

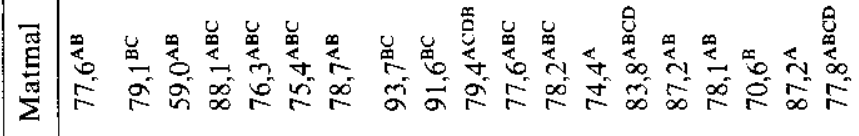

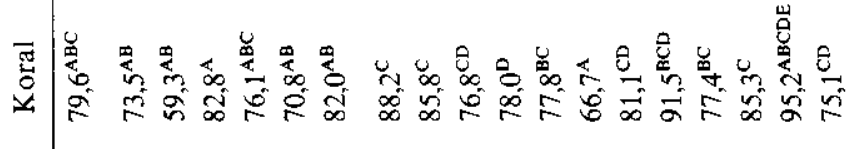

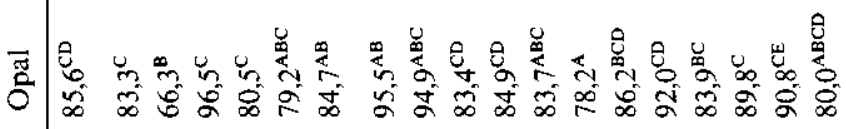

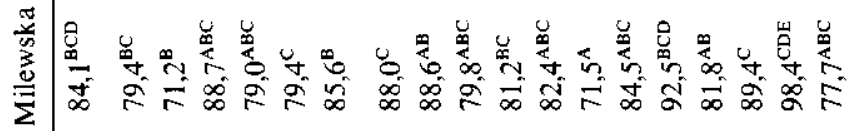

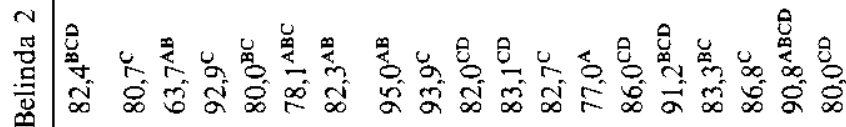

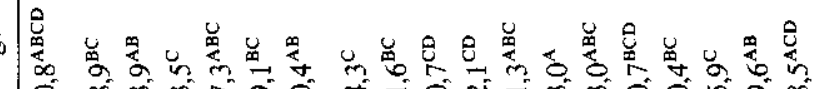

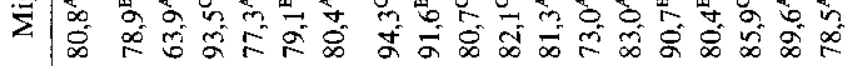

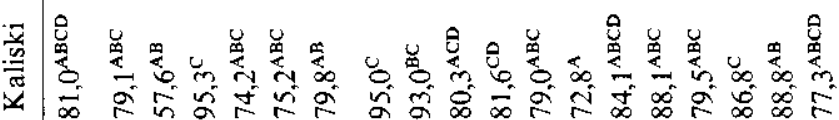


The faecal true protein digestibility ranged from 81 to 88 and from 74 to 78 for white- and coloured-flowered pea, respectively (Table 5). Mathematical analysis showed that it was negatively correlated with pea tannins $(P<0.01)$, while the effects of NDF and trypsin inhibitor were negligible.

In experiments with laying hens, Lindgren (1975) obtained a strong correlation between the digestion coefficients of crude protein and the tannin content. Faccal true digestibility coefficients of most of the amino acids were generally higher in comparison with those calculated for the small intestine. However, the total digestibility of methionine was still low and in some cases even lower than the ileal one. This phenomenon was probably caused by the microbiological synthesis of this amino acid in the hind gut of pigs.

In general, the ileal and faecal digestibilities of nitrogen and amino acids of white-flowered peas were higher than that of coloured-flowered peas. However, there were also meaningful differences in digestibilities among varjeties belonging to the same type of pea.

\section{CONCLUSIONS}

The chemical composition of pea differs widely not only between the two types, white- and coloured-flowered peas, but also from on variety to antoher. Tabular values cannot therefore be accurate.

The protein of white-flowered varieties is digested better than that of coloured-flowered peas in pigs. There was a significant negative correlation between the ileal protein digestibility and the amount of NDF in peas. Tannins were shown to be the main factor negatively influencing the digestibility of protein.

More observations are needed to predict ileal protein digestibility of different peas on the basis of their chemical composition.

\section{REFERENCES}

Adams, C.A., Novellic, K., 1975. Composition and structure of protein bodies and spherosomes isolated from ungerminated seeds of Sorghum bicolar (Linn). Moench. Plant Physiology 55, 1-6

Bajaj, S., Mickeisen, O., Baker, L.R., Markarian, D., 1971. The quality of protein in various lines of pcas. Br. J. Nutr., 25, 207-212

Buraczewska, L., E. Schulz, H. Schröder, 1987. Ileal digestibility of amino acid in pigs fed barleys differing in protein content. Arch. Anim. Nutr., Berlin 37, 861-867

Evans. M., D. Bout]er, 1980. Crude protein and amino acid contents of some commercial varjeties of peas and beans. J. Sci. Food Agric. 31, 238-242

Gatel, F., F. Grosjean, 1990. Composition and nutritive value of peas for pigs: a revicw of European results. Livest. Prod. Sci. 26, 155-175

Griffiths, D.W., 1979. The inhibition of digestive enzymes by extracts of field bean (Vicia faba). J. Sci. Food Agric. 30, 458-462

Griffiths, D.W., 1981. The polyphenolic content and enzyme inhibitory activity of testes from bean (Vicia faba) and pea (Pisum spp.) varieties. J. Sci. Food Agric., 32, 797-804

Griffiths, D.W., 1984. The trypisn and chymotrypsin inhibitor activities of various pea (Pisum spp.) and field bean (Vicia faba) cultivars. J. Sci. Food Agric., 35, 481-486 
Griffiths, D.W., Moseley G., 1980. The sffect of diets containing field beans of high or low polyphenolic content on the activity of diegtestive enzymes in the in testines of rats. J. Sci. Food Agric.. 31. 458-462

Holl, F.B., Vose J.R., 1980. Carbohydrate and protein accumulation in the developing field pea seed. Can. J. Plant Sci, 60, 1109-1114

Horszcraruk, F., Zebrowska, T., Dobrowolski, W, 1972. Trwałe przetoki jelitowe do badań nad trawieniem u świń. III. Wykonanie prostych przetok jelita cienkiego. Rocz. Nauk rol., B-94, $99-105$

Jerumaisn, J., 1972. Über die Veranderung der Polyphenole in Verlauf des Malzens und Maischens. Brauwissenschaft 25, 313-322

Kakade, M.C., J.J. Rackis, J.E. McGhee, G. Puski, 1974. Determination of trypsin inhibitor activity of soy produets, collaborative analysis of an improved procedure. Cereal Chem., 51, 376-382

Knabe, D.A., LaRue, D.C., Greg, E.J., Martinez, G.M., Tanksley, T.D., Jr., 1989. Apparent digestibility of nitrogen and amino acids in protein feedstuffs by growing pigs. J. Anim. Sci., 67 , $441-458$

Leterme, P., Y. Beckers, A. Thewis, 1990a. Trypsin inhibitors in peas: varietal effect and influence on digestibility of crude protein by growing pigs. Anim. Feed Sei. Tech.. 29, 45-55

Leterme, P., Thewis, A., Beckers, Y.. Baudart, E., 1990b. Apparent and true ifeal digestibility of amino acids and nitrogen balance measured in pigs with ileo-rectal anastomosis or $t$-cannulas given diet containing peas. J. Sci. Food Agric., 52, 485-497

Lindgren, E., 1975. The nutritive value of peas and field beans for hens. Swedish J. agric. Res., 5 , 159-16]

McLeod, M.N., 1974. Plant tannins - their role in forage quality. Nutr. Abstr. Rev, 44, 803-815

Reichert, R., S.L. McKenzic, 1982. Composition of peas (Pisum sativum) varying widely in protein content J. Agric. Food Chem., 30, 312-317

Stanogias, G., Pearce. G.R., 1985. The digestion of fibre by pigs. 1. The effeets of amount and type of fibre on apparent digestibility, nitrogen balance and rate of passage. Br. J. Nutr., 53, 513-530

Taverner, M.R.. Hune, I.D., Farrel, D.J.. 1981. Availability to pigs of amino acids in cereal grains. Endogenous levels of amino acids in digesta and faeces in pigs given cercal grain. Br. J. Nutr., 46, $149-158$

Valdebouze, P., Begeron, E., Gaborit, T., Delort-Laval, J., 1980. Content and distribution of trypsin inhibitors and hemagglutinins in some legume seeds. Can. J. Plant Sci., 60. 695-701

Żebrowska, T., Buraczewska. L., Żebrowska, H.. 1981. Influence of crude fibre on protein and amino acid digestibility in growing pigs. In: T. Żebrowska. L. Buraczewska. S. Buraczewski, J. Kowalczyk (Eds.). Procedings of VIth International Symposium on Amino Acids, Scrock, pp. 142-1 46. Polish Scientific Publishers, Warszawa 1984

\section{STRESZCZENIE}

\section{Sklad chemiczny nasion różnych typów i odmian grochu oraz trawienie ich bialka przez świnie}

Zbadano skład ehemiczny, w tym zawartośc niektórych crynników antyrywieniowych oraz przebieg trawienia składników pokarmowych nasion sześciu odmian grochu $\mathrm{i}$ trzech peluszki. Strawnośc białka i aminokwasów oznaczono do konca jelita cienkiego i $w$ całym prrewodzie pokarmowym rosnących świń. W nasionach pelusski, w porównaniu z nasionami grochu, stwierdzono więcej NDF $(\mathrm{P}<0.05)$, ligniny Klasona ora/ tanin $(P<0,0)$ ). Axtywność inhibitora trypsyny w obu lypach nasion wahała się w szerokich granicach i nio różniła się istotnie. Stwierdzono ujemną wspótzależność miẹdzy zawartością białka, a oznaczona w nim ilością metioniny, cystyny i treoniny. Strawnośc rzec/ywista biatka oznaczona do konca jelita cienkiego wynosila od 66 do 83 . a $w$ catym przewodzie pokarmowym od 74 do 88 . Badane odmiany najbardziej rózniły się strawnością jelitowa metioniny, cystyny i tryptofanu. Stwierdzono, ze spośród występujących w nasionach czynników (NDF, taniny, inhibitor trypsyny), wplyw NDF na strawnosic jelitową biakka był największy, podezas gdy taniny najsilnicj ograniczaly jego strawność ogólną. 